\title{
What meaning for sustainability? The role of tourism academics in securing impact
}

Fernando Correia, Hull University Business School, Hull, HU6 7RX, UK

Font's (2017) article raises a series of relevant questions directly related to ongoing debates in both tourism research and wider academia on the nature of sustainability and the role of the researcher in its advancement. The latter is particularly pertinent at a time when in the UK academics are increasingly expected to create and demonstrate impact from their research work, in the context of the periodic Research Excellence Framework (REF) evaluation exercise (Martin, 2011; Smith, Ward, \& House, 2011).

One of the first questions the article generates is what do we actually mean by impact in tourism, and particularly in 'sustainable tourism'? As Font notes, the latter should mean something similar to 'creating a positive benefit on the triple bottom line of the environment, society and the economy'. However, it is highly questionable if we can really expect academics to be experts or generators of impact on all of those dimensions. Additionally, as most scholars of sustainability are deeply aware, any attempts to advance sustainability usually mean engaging in debates about trade-offs and valuebased decisions about what dimension(s) we, as society, are willing to advance at the expense of others. This naturally leads to another set of uneasy questions about which dimensions academic are expected to further, how and why...

Engaging in such debates should first require us to take a step back and revisit more fundamental questions over what is tourism, or even what is tourism for? On the former question, and whether for convenience or uncritical reasons, it is all too common simply to accept generic definitions from UNWTO (United Nations World Tourism Organization) as a starting point and move on from there. However, matters do not necessarily get clearer when the latest of such definitions simply states that 'tourism refers to the activity of visitors' (UNWTO, 2014), with a visitor in turn defined as

'a traveller taking a trip to a main destination outside his/her usual environment, for less than a year, for any main purpose (business, leisure or other personal purpose) other than to be employed by a resident entity in the country or place visited' (UNWTO, 2010, p.10).

In other words, it can be anything but simple to identify clear differences between the needs and activities of a visitor and those of a resident of a host community. Very often at a destination level what we would call a tourism industry is rather a constellation of firms and services that cater to both visitors and residents in varying degrees and formats. The focus of this particular journal on 'tourism, leisure and events' is a perfect example of three artificial concepts that in practice can overlap significantly and complicate any distinctions between visitors and residents as 'target public' of their respective foci. It is true that there are some sectors such as transportation and accommodation that can have a greater emphasis on the needs of a 'visitor', but even those are commonly staffed by 'residents', which blurs again any clear cut answers about whose needs are being served by such businesses or activity. Thinking back to Font's theme, the challenges above generate further complex questions such as creating impact for whom, and exactly what policy context(s) are we talking about when we talk about sustainable tourism?

This leads us to the second question of what is (sustainable) tourism for, and what does 'creating impact' mean if that is to be the question framing policy. Addressing these should lead us to re-engage with what Font (2017), picking up on Sharpley (2000) calls the 'more meaningful debate of whether the purpose of sustainable tourism is to make the tourism industry more sustainable, or to use tourism as a tool for sustainable development. The previous paragraph was making the point that is not really possible to separate tourism from matters of local/regional/national development as, if anything, tourism is the sum of a wide range of activities and services in which both visitors and host 
communities take part. In that sense, the second option above appears to be the more obvious, but that requires moving towards a systems perspective and an interdisciplinary approach to tourism that has, for the most part, been absent in sustainable tourism research (Liu, 2003). Hunter's (1995) early criticism of the paradigm of sustainable tourism was that it was too tourism-centric and parochial, and Font's piece confirms that not much has changed in the two decades since. Most efforts in the field are still sector- or product-centred and ignore the wider intersectoral, socio-economic and geographical context in which they are embedded. One could argue that the trend in academia (in the UK at least) to move tourism departments from geography to business schools is but a reflection and reinforcement of such self-centered tendencies, further narrowing the focus of attention of researchers to aspects that are mostly relevant (or impactful) to the business or market dimensions of tourism. For all its valid criticisms and observations on the limitations of market based instruments, Font's article ends up being yet another manifestation of how such developments have been gradually narrowing what we allow ourselves to contemplate as 'thinkable' in tourism. Because if, as he says, the limited success of such instruments is 'frankly depressing for the academic that aims to have impact', that is also a sign that we have stopped giving enough consideration to the wider plethora of instruments and tools beyond market based ones (Howlett, 2010). Perhaps we 'went native' and started inhabiting or operating mainly within the institutional models, norms or rules of 'the industry' - and that can indeed be a 'slippery policy context'.

Therefore, every so often it is worth taking a step back and reconsidering those fundamental questions about what tourism is and what it is for. If an industry-based policy can perhaps only provide industryfocused answers, a wider public policy approach to tourism should (in theory) recognize its interactions and deep linkages to other policy domains, including environmental, employment, education, social, or even public health, policies. Recognizing and directly addressing such interlinkages is likely to do more to advance sustainable tourism than any industry or product-centred initiative. We would probably be unwilling to contemplate market based instruments as the only solutions available for those other public policy domains, so we should equally challenge why the opposite seems acceptable when it comes to tourism.

Failure to do so will find us as researchers where Font's article has left us: trying to create impact with attempts to change the industry from within, hoping that somehow, some players can act as some type of Trojan horse (or 'demonstration project' that can be scaled up and replicated by the majority), and getting frustrated at the results. But as long as sustainability is seen by the industry mainly as a source of competitive advantage (Hassan, 2000; Lee, Hsu, Han, \& Kim, 2010; Shaalan, 2005), such an approach is more likely to reinforce than challenge any existing business paradigms. Meanwhile, one wonders if the best chances for a researcher to create impact in/for sustainable tourism actually reside outside tourism, by engaging in the shaping of wider societal values. After all, most of the progress in sustainable tourism so far has come from the industry responding to gradual changes in such values, rather than leading that change.

\section{References}

Font, X. (2017). Creating impact in a slippery policy context: sustainable tourism. Journal of Policy Research in Tourism, Leisure and Events,

Hassan, S. S. (2000). Determinants of Market Competitiveness in an Environmentally Sustainable Tourism Industry. Journal of Travel Research, 38(3), 239-245. http://doi.org/ER -

Howlett, M. (2011). Designing Public Policies: Principles and Instruments. Oxon, Routledge.

Hunter, C. J. (1995). On the need to re-conceptualise sustainable tourism development. Journal of Sustainable Tourism, 3(3), 155-165. http://doi.org/10.1080/09669589509510720 
Lee, J.-S., Hsu, L.-T. (Jane), Han, H., \& Kim, Y. (2010). Understanding how consumers view green hotels: how a hotel's green image can influence behavioural intentions. Journal of Sustainable Tourism, 18(7), 901-914. http://doi.org/10.1080/09669581003777747

Liu, Z. (2003). Sustainable Tourism Development: A Critique. Journal of Sustainable Tourism, 11(6), 459-475.

Martin, B. R. (2011). The Research Excellence Framework and the 'impact agenda': are we creating a Frankenstein monster? Research Evaluation, 20(3), 247-254. http://doi.org/10.3152/095820211X13118583635693

Shaalan, I. M. (2005). Sustainable tourism development in the Red Sea of Egypt threats and opportunities. Journal of Cleaner Production, 13(2), 83-87. http://doi.org/10.1016/j.jclepro.2003.12.012

Sharpley, R. (2000). Tourism and Sustainable Development: Exploring the Theoretical Divide. JOURNAL OF SUSTAINABLE TOURISM, 8(1), 1.

Smith, S., Ward, V., \& House, A. (2011). 'Impact' in the proposals for the UK's Research Excellence Framework: Shifting the boundaries of academic autonomy. Research Policy, 40(10), 1369-1379. http://doi.org/10.1016/j.respol.2011.05.026

UNWTO. (2010). International Recommendations for Tourism Statistics 2008 (Economic \& Social Affairs No. ST/ESA/STAT/SER.M/83/Rev.1). New York: United Nations, World Tourism Organization. Retrieved from http://unstats.un.org/unsd/publication/Seriesm/SeriesM_83rev1e.pdf\#page=21

UNWTO. (2014). Glossary of tourism terms. Retrieved 26 September 2016, from http://cf.cdn.unwto.org/sites/all/files/Glossary+of+terms.pdf

Fernando Correia

Lecturer in Sustainable Business Management

Hull University Business School

Cottingham Road

Hull

HU6 7RX

f.correia@hull.ac.uk 